\title{
An analysis of the Tvergaard parameters at low initial stress triaxiality for S235JR steel
}

Paweł G. Kossakowski, Ph.D.

Kielce University of Technology

\begin{abstract}
This paper discusses the influence of the Tvergaard parameters, qi, which are basic constants of the Gurson-TvergaardNeedleman (GTN) material model, on the numerically simulated load-carrying capacity of tensile elements made of S235JR steel. The elements were considered to be under static tension at low initial stress triaxiality $\sigma_{m} / \sigma_{e}=1 / 3$. Two sets of the Tvergaard parameters $q_{i}$ were analyzed: those typical of structural steels and those dependent on material strength properties. The results showed that the Tvergaard parameters, qi, had influence on the load-carrying capacity of tensile elements at low initial stress triaxiality. They affected the strength curves and the changes in the void volume fractions determined for S235JR steel elements
\end{abstract}

Keywords: Tvergaard parameters, Gurson-Tvergaard-Needleman material model, GTN, S235JR steel

\section{Introduction}

When analyzing strength of plastically deformed metal elements, we need to consider failure processes, as they are strongly connected with the material microstructure, and more specifically, with the presence of microstructural defects. Ductile fracture, for example, is mainly due to microdefects in the form of voids at inclusions and second-phase particles in the material matrix. Nucleation, growth and coalescence of voids lead to material failure (Fig. 1).

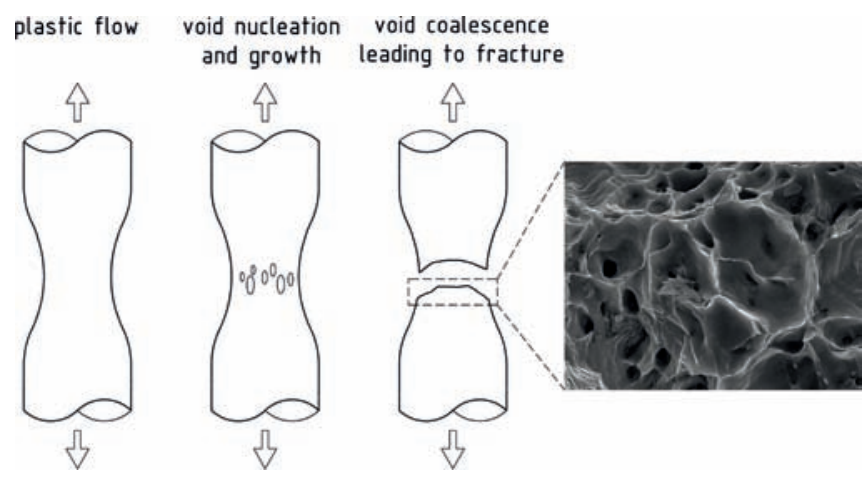

Fig. 1. Micromechanism of ductile fracture and the view of S235JR steel microstructure
The growth and coalescence of voids resulting in the development of localized plastic deformations have the greatest impact on material failure.

In order to numerically simulate the ductile fracture process, it is necessary to use advanced material models, based on damage mechanics. These models take into consideration the influence of microstructural defects on material strength, which requires defining the crack pattern in particular failure stages. An example of such a model is the modified GursonTvergaard-Needleman (GTN) material model based on the Gurson material model developed for a porous solid by Gurson (1977). In the original Gurson material model, the relation between the increase in the void volume fraction and the strength of the material was defined by transforming the Huber-Mises-Hencky criterion. The Gurson material model was later modified by Tvergaard (1981), who introduced some microstructural parameters and plastic properties, jointly termed parameters $\mathrm{q}_{\mathrm{i}}$. The model was further modified by Tvergaard and Needleman (1984) and Needleman and Tvergaard (1984), who suggested analyzing the critical void volume fraction at the moment of total failure. In the literature, this form of the model is referred as the GursonTvergaard-Needleman (GTN) material model.

The GTN material model has been implemented in many commercial numerical programs. In construction 
engineering, it is recommended for use in the analysis of pre-failure condition of structural elements, as can be read, for example, in Sedlacek et al. (2008), Kossakowski (2010, 2012a, 2012b, 2012c, 2012d), Kossakowski and Trąmpczyński (2012) and Eurocode PN-EN 1993-1-10 (2005). This solution has numerous industrial applications, including ship building and maintenance. It mainly concerns emergency states observed in structural ship elements made of ship steel, and other elements made of normal strength steel. It should be noted that the GTN material model is being continually developed, (see, for instance, Nahshon and Hutchinson (2008), and there are still some problems that need to be solved, as shown in Ruggieri (2004). In numerical simulations performed for structural steel elements, the main drawback is the lack of standardized GTN microstructural parameters, which makes the GTN model difficult to use for common engineering calculations.

In this study, the Tvergaard parameters, which are some of basic material constants of the GTN model, were analyzed with regard to their influence on the behaviour of elements made of common structural steel, S235JR, which is used in shipbuilding. The presented analysis is part of a wider research project focused on the standardization of GTN parameters for this steel grade. The simulations were conducted for unnotched specimens under tension in a low stress state defined by initial stress triaxiality $\sigma_{\mathrm{m}} / \sigma_{\mathrm{e}}=1 / 3$, where $\sigma_{\mathrm{m}}$ and $\sigma_{\mathrm{e}}$ denote the mean and effective stress, respectively. If we consider the usefulness of the GTN material method for analyzing the load-carrying capacity in engineering calculations, we can conclude that the results of the study can be used to model and assess the load-carrying capacity and safety of structural elements made of S235JR and other steels with similar strength properties and metallurgical composition.

\section{Tvergaard parameters in the GTN material model}

The modifications of the original Gurson material model performed by Tvergaard (1981) for porous media involved introducing parameters qi to describe plastic properties of the material

$$
\Phi=\left(\frac{\sigma_{e}}{\sigma_{0}}\right)^{2}+2 q_{1} f_{\cosh }\left(q_{2} \frac{\sigma_{k}}{2 \sigma_{0}}\right) \underline{k}\left(1+q_{3} f^{2}\right)=0
$$

where: $\sigma_{\mathrm{e}}-$ effective stress in accordance with the HuberMises-Hencky $(\mathrm{HMH})$ criterion, $\sigma_{0}$ - yield stress of the material, $\sigma_{\mathrm{kk}}$ - first invariant of the stress state, $f$ - void volume fraction, $q_{i}$ - Tvergaard parameters describing plastic properties of the material.

In the original Gurson's condition, $\mathrm{q}_{1}=\mathrm{q}_{2}=\mathrm{q}_{3}=1$.

Further modifications of criterion (1) by Tvergaard and Needleman (1984) involved defining the modified void volume fraction $\mathrm{f}^{\star}$

$$
f^{*}= \begin{cases}f & \text { for } \quad f \leq f_{c} \\ f_{c}+\frac{\bar{f}_{F}-f_{c}}{f_{F}-f_{c}}\left(f-f_{c}\right) & \text { for } \quad f>f_{c}\end{cases}
$$

where: $f_{c}$ - critical void volume fraction at which the void coalescence begins, $\mathrm{f}_{\mathrm{F}}$ - void volume fraction corresponding to complete material strength loss at final failure, $\bar{f}_{F}$ - constant.

After the modifications, the yield criterion was written as

$$
\Phi=\left(\frac{\sigma_{e}}{\sigma_{0}}\right)^{2}+2 q_{1} f^{*} \cosh \left(q_{2} \frac{\sigma_{k}}{2 \sigma_{0}}\right) \underline{k}\left(1+q_{3} f^{* 2}\right)=0
$$

As can be seen from this GTN constitutive law (3), the Tvergaard parameters, $\mathrm{q}_{\mathrm{i}}$, influence the yield domain. The relation between parameters qi and the material behaviour was summarized by Corigliano et al. (2000). According to the GTN yield condition (3), the first Tvergaard parameter, $\mathrm{q}_{1}$, affects the yield domain by modifying the actual void volume fraction $\mathrm{f}^{\star}$. When $\mathrm{q}_{1}>1.0$, the plastic limit occurs at reduced stress levels.

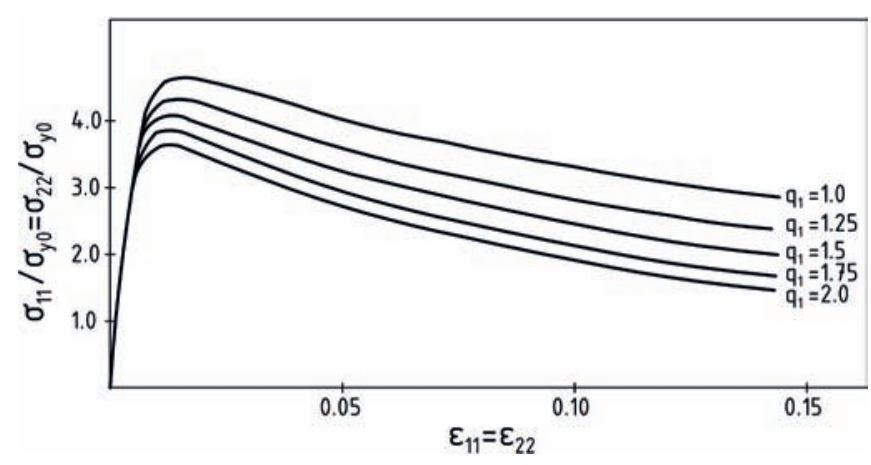

Fig. 2. Nonlinear material response affected by the Tvergaard parameters, according to the GTN constitutive law at $\varepsilon_{22} / \varepsilon_{11}=1.0$ for $1.0 \leq \mathrm{q}_{1} \leq 2.0$ (Corigliano et al., 2000).

The higher the value of the parameter $\mathrm{q}_{1}$, the lower the strength properties of the material modelled according to the GTN yield condition.

The Tvergaard parameter $\mathrm{q}_{1}$ affects the stress-strain relation $\sigma(\varepsilon)$ by reducing the material stress carrying capacity. The softening effects, which are due to void growth in the matrix material, predominate over the hardening effects. The higher the value of $\mathrm{q}_{1}$, the stronger the softening of the material (Fig. 2). Tvergaard (1981) suggested that the optimal value of $\mathrm{q}_{1}$, which is 1.5 , could be used for numerical modelling of localized plastic deformations and fracture phenomena for many porous solids, including metals.

As can be seen from the yield condition (3), parameter $\mathrm{q}_{2}$ corrects the first invariant of the stress state $\sigma_{\mathrm{kk}}$, which 
is a function of the hydro-static component $\sigma_{\mathrm{m}}=\sigma_{\mathrm{kk}} / 3$. When the values of $\mathrm{q}_{2}$ are high, the yield strength is reduced considerably. Tvergaard (1989) assumed that, optimally, $\mathrm{q}_{2}=$ 1.0. For high values of $\mathrm{q}_{2}$, strong softening is induced due to the growth of voids in the matrix material, with this implying the annihilation of the strain hardening properties (Fig. 3). As a result, according to the GTN model, there is a reduction in overall strength properties of the porous material.

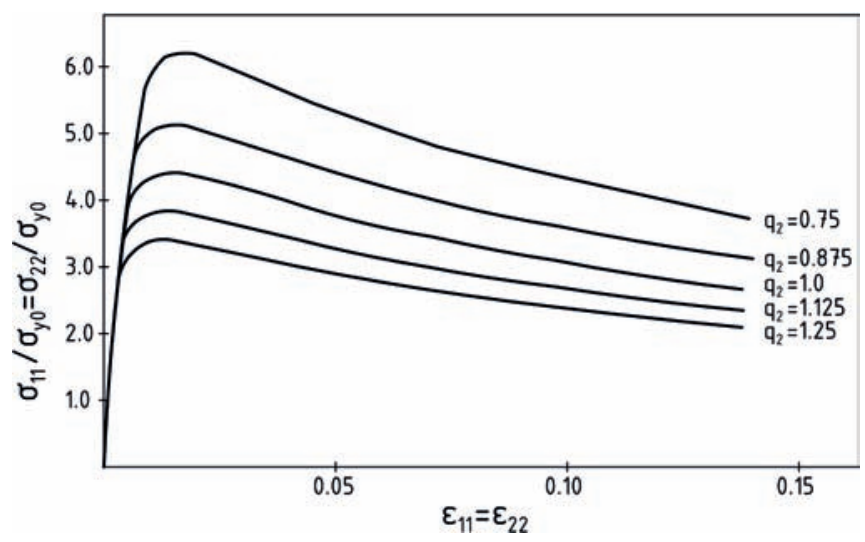

Fig. 3. Nonlinear material response affected by the Tvergaard parameters according to the GTN constitutive law at $\varepsilon_{22} / \varepsilon_{11}=1.0$ for $0.75 \leq \mathrm{q}_{2} \leq 1.25$ (Corigliano et al., 2000)

To summarize, the typical values of the Tvergaard parameters assumed for many metals and steels are:

$$
\mathrm{q}_{1}=1.5, \mathrm{q}_{2}=1.0 \text { and } \mathrm{q}_{3}=\mathrm{q}_{1}^{2}=2.25 \text {. }
$$

For many years these values were treated as constants. The analysis performed by Falsekog et al. (1998) revealed that the Tvergaard parameters were dependent on elastic-plastic properties of the material, especially the strain hardening exponent $\mathrm{N}$ and the relation between the yield stress, $\sigma_{0}$, and the modulus of elasticity, E, as shown in Figs. 3 and 4.

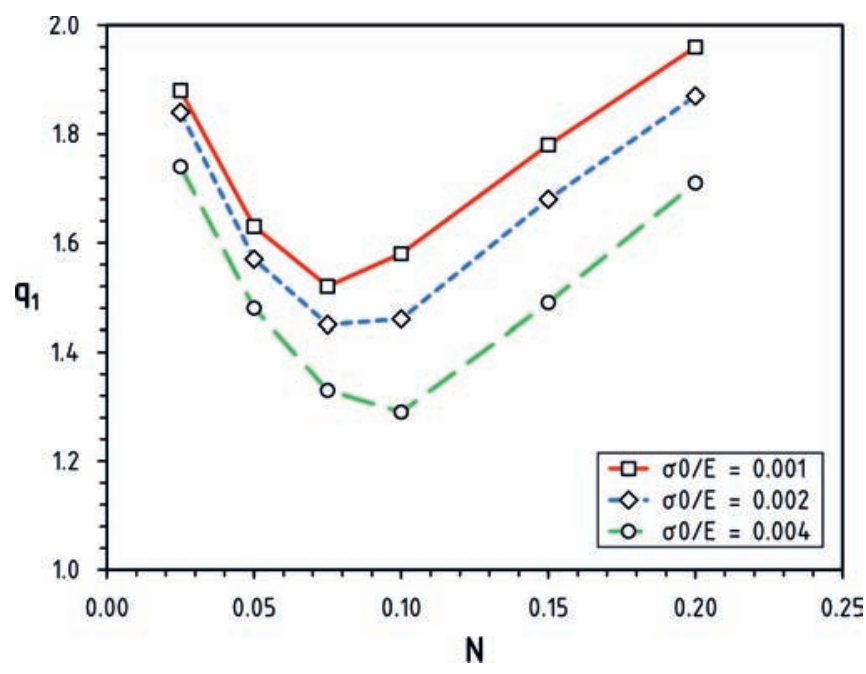

Fig. 4. q1 vs. strain hardening exponent, $N$, at different $\sigma 0 / \mathrm{E}$ ratios (Faleskog et al., 1998)

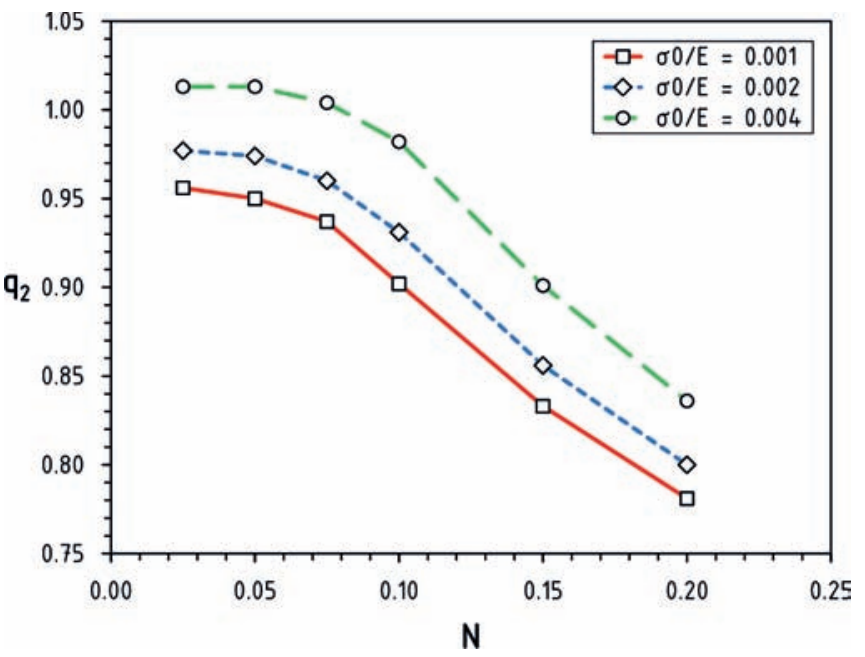

Fig. 5. $\mathrm{q}_{2}$ vs. strain hardening exponent, $\mathrm{N}$, at different $\sigma_{0} / \mathrm{E}$ ratios (Faleskog et al., 1998)

\section{Scope of the analysis}

This study was conducted for tensile elements in a low stress state, at initial stress triaxiality $\sigma \mathrm{m} / \sigma \mathrm{e}=1 / 3$. Static tension was applied to specimens with a circular cross-section at increased control of displacements. The analysis was performed in two stages: experimental tests and numerical calculations. The modified GTN material model was developed according to criterion (3). The material parameters determined for S235JR steel were: the parameters based on the elastic-plastic model, the Tvergaard parameters, and the parameters obtained by applying the GTN material model. Special attention was paid to the Tvergaard parameters.

\section{Material parameters of S235JR steel}

\section{Material parameters according to the elastic-plastic model}

The elastic-plastic model for S235JR steel was developed according to PN-EN 10002-1 (2004) using the results of the standard static tensile strength tests performed by Kossakowski (2012a). The specimens had a circular crosssection with the primary cross-sectional area $S_{0}=78.5$ $\mathrm{mm} 2$, the nominal diameter $\mathrm{d}=10 \mathrm{~mm}$, and the length of the measuring base $1_{0}=50 \mathrm{~mm}$. The average strength parameters obtained during the tests were: the yield stress $\sigma_{0}=318 \mathrm{MPa}$, the tensile strength $\mathrm{R}_{\mathrm{m}}=446 \mathrm{MPa}$, and the percentage elongation $\mathrm{A}=33.9 \%$.

The strength curves $\sigma(\varepsilon)$, showing the relation between the nominal normal stress, $\sigma$, and the longitudinal strain, $\varepsilon$, were used to develop the elastic-plastic material model for S235JR steel. The tensile strength curves were approximated by Kossakowski (2012a) to: 


$$
\begin{array}{lll}
\varepsilon=\frac{\sigma}{E} & \text { f o r } & \sigma<\sigma_{0} \\
\varepsilon=\frac{\varepsilon_{h}-\varepsilon_{0}}{\sigma_{h}-\sigma_{0}}\left(\sigma-\sigma_{0}\right)+\varepsilon_{0} & \text { f o r } & \sigma_{0} \leq \sigma \leq \sigma_{h} \\
\varepsilon=\varepsilon_{0}+\frac{\sigma_{n}}{E}\left(\frac{\sigma}{\sigma_{n}}\right)^{1 / N} & \text { f o r } & \sigma>\sigma_{h}
\end{array}
$$

where: $\varepsilon$ - strain, $\varepsilon_{0}$ - yield strain, $\varepsilon_{\mathrm{h}}$ - initial hardening strain, $\sigma$ - stress, $\sigma_{0}-$ yield stress, $\sigma_{\mathrm{h}}$ - initial hardening stress, $\sigma_{n}-$ initial stress at the starting point of nonlinearity in the approximation curve, $\mathrm{E}$ - modulus of elasticity, $\mathrm{N}$ - strainhardening exponent.

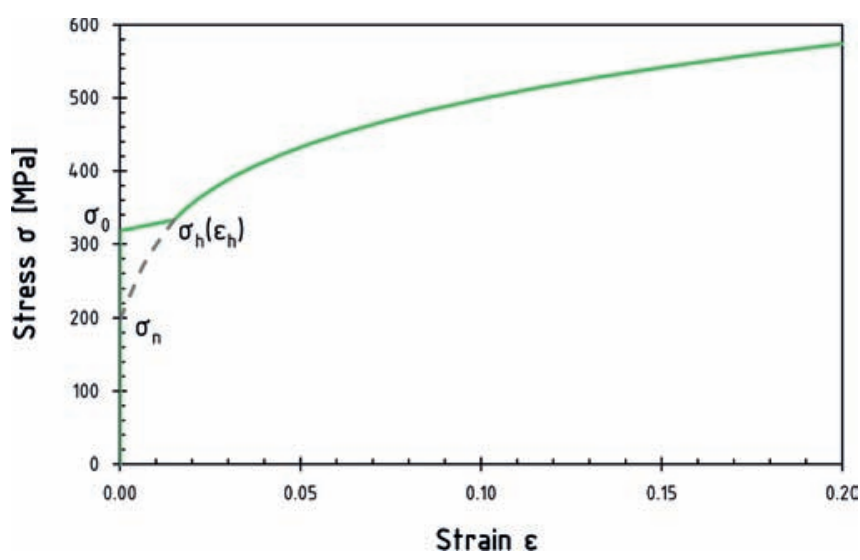

Fig. 6. Approximation material model for S235JR steel (Kossakowski, 2012a)

Table 1. Strength parameters of S235JR steel (Kossakowski, 2012a)

\begin{tabular}{|c|c|c|c|c|c|c|}
\hline$\varepsilon_{0}$ & $\varepsilon_{\mathrm{h}}$ & $\begin{array}{c}\sigma_{0} \\
{[\mathrm{MPa}]}\end{array}$ & $\begin{array}{c}\sigma_{\mathrm{n}} \\
{[\mathrm{MPa}]}\end{array}$ & $\begin{array}{c}\sigma_{\mathrm{h}} \\
{[\mathrm{MPa}]}\end{array}$ & $\begin{array}{c}\mathrm{E} \\
{[\mathrm{GPa}]}\end{array}$ & $\mathrm{N}$ \\
\hline 0,002 & 0,015 & 318 & 198 & 333 & 205 & 0,195 \\
\hline
\end{tabular}

\section{The Tvergaard parameters}

Two sets of the Tvergaard parameters were considered for S235JR steel. One set contained values typical of many metal materials:

$$
q_{i}=\left\{\begin{array}{l}
q_{1}=1.5 \\
q_{2}=1.0 \\
q_{3}=q_{1}^{2}=2.25
\end{array}\right.
$$

In the other set the values were determined with regard to the strength properties of S235JR steel: the yield stress $\sigma_{0}$ $=318 \mathrm{MPa}$, the modulus of elasticity $\mathrm{E}=205 \mathrm{GPa}$, and the strain-hardening exponent $\mathrm{N}=0.195$, using the relations presented by Faleskog et al. (1998). The values of the Tvergaard parameters established from the relation shown in Figs. 4 and
Fig. 5 at $\sigma_{0} / \mathrm{E}=0.00155$ and $\mathrm{N}=0.195$ were:

$$
q_{i}=\left\{\begin{array}{l}
q_{1}=1.91 \\
q_{2}=0.79 \\
q_{3}=q_{1}^{2}=3.65
\end{array}\right.
$$

\section{Material parameters according to the GTN material model}

As can be seen from criterion (3), the modified GTN model is an advanced model which requires many material constants including the Tvergaard parameters.

The initial void volume fraction $\mathrm{f}_{0}$ is a fundamental GTN parameter describing the material porosity. It was determined on the basis of the microstructural images of S235JR steel (Fig. 7).

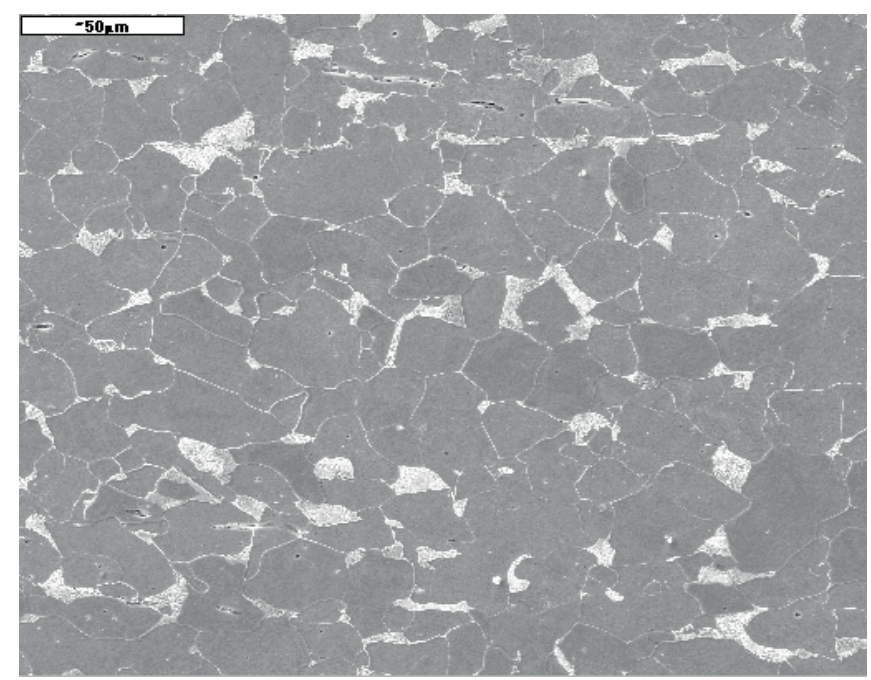

Fig. 7. SEM image of S235JR steel

S235JR steel had a typical ferritic-perlitic matrix with a large number of non-metallic inclusions, mainly sulphides and brittle oxides. The initial porosity of the material was established by determining basic stereological parameters. The effect of initial porosity at low stress triaxiality for S235JR steel was analyzed by Kossakowski (2012b). The values obtained for different areas in several longitudinal and transverse sections of the specimens were used to determine the average value of the initial void volume fraction $\left(\mathrm{f}_{0}=0.001\right)$.

The remaining material parameters according to the GTN model were determined from the $\sigma(\varepsilon)$ curves obtained through experimental tests and numerical simulations. The GTN material model parameters were changed within certain limits at each iteration step, using the optimization criterion based on the agreement of the numerical and experimental data concerning the $\sigma(\varepsilon)$ relation. The numerical analysis was performed applying the Finite Element Method based program Abaqus Explicit version 6.10 (2010). The tensile elements were modelled as axially symmetrical using standard finite elements. 
The critical void volume fraction at the onset of coalescence, $f_{c}$, determined from the results obtained by Richelsen and Tvergaard (1994) as well as by Kossakowski (2010, 2012a, 2012b, 2012c, 2012d) and Kossakowski and Trąmpczyński (2012), was equal to 0.06 . In order to analyze the whole range of failure and minimize the softening effect, it was assumed that the critical void volume fraction at the onset of fracture, $\mathrm{f}_{\mathrm{F}}$, corresponding to complete material strength loss was 0.667 , which was the maximal theoretical value of $f_{F}$.

An increase in the void volume fraction $\dot{f}$ in the modified GTN model (3) was written as

$$
\dot{f}=\dot{f}_{g r}+\dot{f}_{\text {nucl }}=(1-f) \dot{\boldsymbol{\varepsilon}}^{p l}: \mathbf{I}+\frac{f_{N}}{s_{N} \sqrt{2 \pi}} \exp \left[-\frac{1}{2}\left(\frac{\varepsilon_{e m}^{p l}-\varepsilon_{N}}{s_{N}}\right)^{2}\right] \cdot \dot{\varepsilon}_{e m}^{p}
$$

where: $\dot{f}_{g r}$ - change due to the growth of voids present in the material, $\dot{f}_{\text {nucl }}$ - change due to the nucleation of new voids, $\mathrm{f}_{\mathrm{N}}$ - volume fraction of the nucleated voids, $\mathrm{s}_{\mathrm{N}}-$ standard deviation of the nucleation strain, $\dot{\boldsymbol{\varepsilon}}^{p l}$ - plastic strain rate tensor, I - second-order unit tensor, $\varepsilon_{\mathrm{N}}$ - mean strain of the void nucleation, $\varepsilon_{e m}^{p l}$ - equivalent plastic strain in the matrix material, $\dot{\varepsilon}_{e m}^{p l}$ - rate of equivalent plastic strain in the matrix material.

The volume fraction of the nucleated voids was $\mathrm{f}_{\mathrm{N}}=0.04$, the mean nucleation strain was $\varepsilon_{\mathrm{N}}=0.30$, and the standard deviation of the nucleation strain was $\mathrm{sN}=0.05$. The GTN parameters used in the present study for S235JR steel for the two Tvergaard's parameter sets are summarized in Table 2.

Table 2. Microstructural parameters of S235JR steel in the GTN model

\begin{tabular}{|c|c|c|c|c|c|c|c|c|c|}
\hline $\begin{array}{c}\text { Model } \\
\text { No. }\end{array}$ & $\mathrm{f}_{0}$ & $\mathrm{f}_{\mathrm{c}}$ & $\mathrm{f}_{\mathrm{F}}$ & $\mathrm{q}_{1}$ & $\mathrm{q}_{2}$ & $\mathrm{q}_{3}$ & $\varepsilon_{\mathrm{N}}$ & $\mathrm{f}_{\mathrm{N}}$ & $\mathrm{s}_{\mathrm{N}}$ \\
\hline 1 & 0.001 & 0.06 & 0.667 & 1.50 & 1.00 & 2.25 & 0.3 & 0.04 & 0.05 \\
\hline 2 & 0.001 & 0.06 & 0.667 & 1.91 & 0.79 & 3.65 & 0.3 & 0.04 & 0.05 \\
\hline
\end{tabular}

\section{Analysis of the Tvergaard parameters for S235JR steel}

The Tvergaard parameters of S235JR steel were analyzed using numerical simulations of the experiments. The calculations were performed by means of the code Abaqus version 6.10 Dynamic Explicit Analysis.

The elements were subjected to tension under displacement-controlled conditions with the strain rate being in the static range $\dot{\varepsilon}=1 \cdot 10^{-2} s^{-1}$. Axially symmetric finite elements were applied to model the specimens with a circular cross-section. Because of the symmetry, halfspecimens were analyzed. In order to initiate the fracture, a sharp notch with $\mathrm{R}=0.05 \mathrm{~mm}$ was modelled in the middle of the specimen length (Fig. 8).

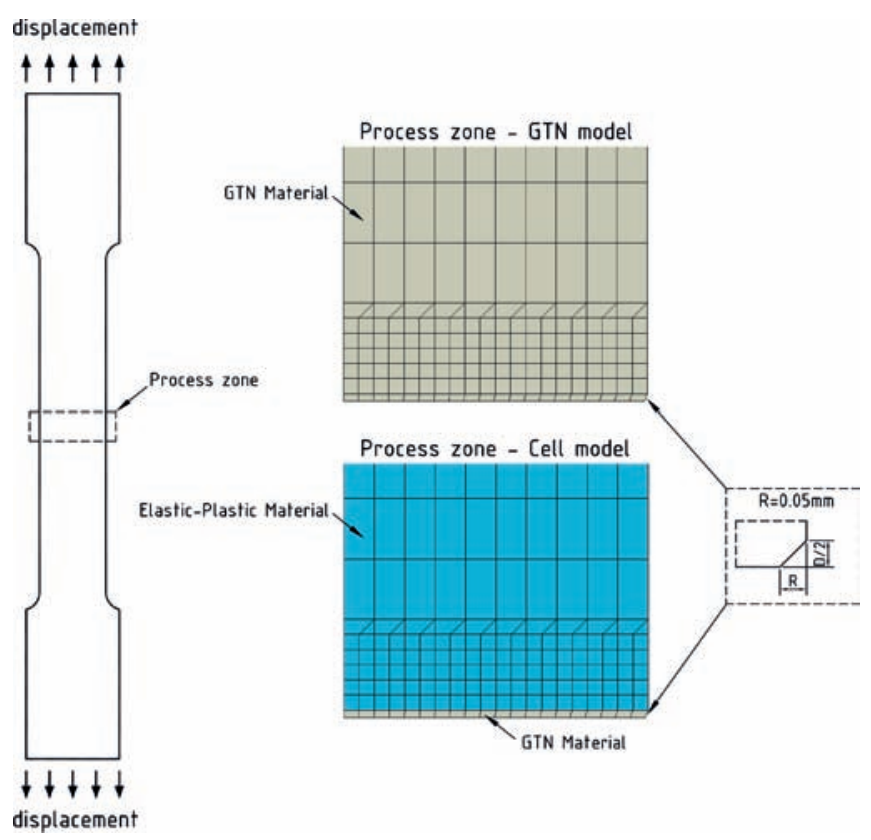

Fig. 8. Specimen and process zone models

The numerical simulations were conducted applying general material models recommended for predicting material failure. The numerical model called GTN used the GTN material model for modelling the whole element. In the numerical model referred to as Cell, the GTN material model was applied to model the areas adjacent to the crack plane, whereas the elastic-plastic material model was employed for modelling the rest of the element. The two numerical models are illustrated in Fig. 8.

The microstructure-based length scale methods were applied to build both of these numerical models. Generally, the length scale methods are based on a fracture criterion related to a minimum volume of material necessary to form a macroscopic crack in the region of high stresses and plastic strain. In two dimensions, this volume is defined by the characteristic length measure 1 . It should be noted that the determination of the length scale is still subjective, although various approaches have been discussed and applied. Here, the Hancock and Mackenzie (1976) method was used. According to this approach, fracture is due to the linking of voids formed from the coalescing inclusion colonies. When the voids grow beyond the clusters boundaries, macrocracks form only if shear stress is localized between multiple clusters. The size of the inclusion colonies defines the length scale, which is visible in a fractograph.

The characteristic length lc for S235JR steel was defined by the dimensions of the plateaus and valleys on the fracture surface, using the results reported by Kossakowski (2012a). The characteristic length $\mathrm{lc}$ ranged from $130 \mu \mathrm{m}$ to $360 \mu \mathrm{m}$ and the average value was $l c \approx 250 \mu \mathrm{m}$, according to the results obtained by Kossakowski (2012a).

In the numerical models, the region close to the fracture plane, i.e. the process zone (Fig. 8), was meshed using the characteristic length $1_{c}=250 \mu \mathrm{m}$, determined through microstructural examinations. The mesh in the process zone was $\mathrm{D} \times \mathrm{D} / 2$, where $\mathrm{D}=1_{\mathrm{c}}=250 \mu \mathrm{m}$. 
The analysis of the Tvergaard parameters for S235JR was performed based on the force-elongation $\mathrm{F}(\Delta \mathrm{l})$ curves determined experimentally and numerically. Two sets of the GTN material parameters were applied (Table 2), using the values of qi according to (5) and (6) for the GTN and the Cell numerical models. The strength curves $\mathrm{F}(\Delta \mathrm{l})$ obtained from experimental tests and numerical simulations for the cases considered are presented in Figure 9 and 10.

As can be seen, the tensile strength curves which were determined numerically by applying both the GTN and the Cell models were consistent with the experimental data from the origin up to the maximum force $\mathrm{F}$. The strength curves obtained numerically using the assumed Tvergaard parameter sets were identical. However, beyond the maximum force until the material failure, the results differed. It was thus essential to analyze the Tvergaard parameters in relation to the load - carrying capacity of S235JR steel elements in the failure range.

When the GTN model was applied, the softening phenomenon was observed in the range beyond the maximum force; it corresponded to the elongation $\Delta \mathrm{l}=8.0 \mathrm{~mm}$ (Fig. 9). Then, the $\mathrm{F}(\Delta \mathrm{l})$ curves decline markedly, which indicates that the values of the force $\mathrm{F}$ determined numerically are lower than those obtained during experiments.

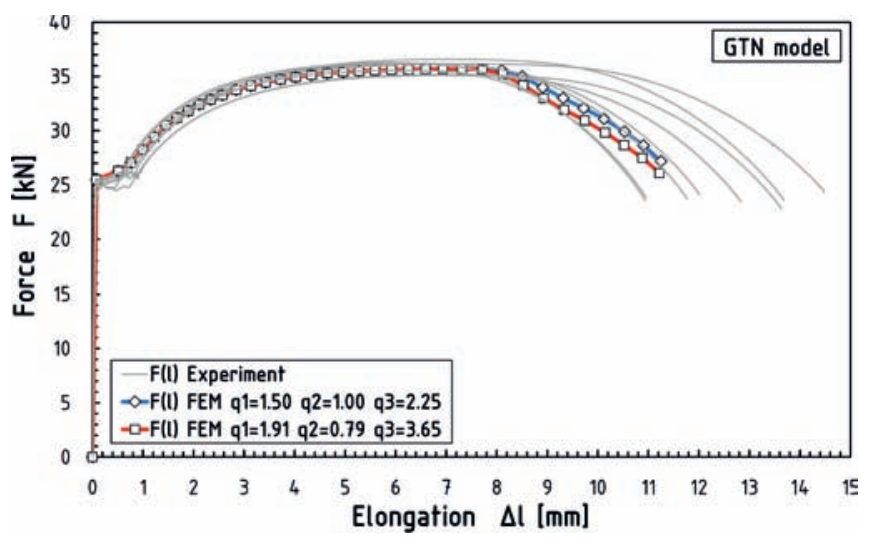

Fig. 9. Force vs. elongation curves determined experimentally and numerically using the GTN model

The values of the force obtained by using the standard Tveergard parameters, i.e. $\mathrm{q}_{1}=1.5, \mathrm{q}_{2}=1.0, \mathrm{q}_{3}=2.25$, were higher than those based on the Tveergard parameters assumed from the material properties, i.e. $\mathrm{q}_{1}=1.91, \mathrm{q}_{2}=0.79, \mathrm{q}_{3}=3.65$. This was true for the range from the maximum force up to the material failure. The maximum difference between the force values was $4.3 \%$.

The softening effects were not observed for the Cell model (Fig. 10). For the range beyond the maximum force, the strength curves $\mathrm{F}(\Delta \mathrm{l})$ were consistent with the maximum range of the strain curves determined during experiments (Fig. 10). Like in the GTN model, differences in the force values were also reported, yet in the opposite direction. The values obtained by using standard Tvergaard parameters, i.e. $\mathrm{q}_{1}=1.5, \mathrm{q}_{2}=1.0, \mathrm{q}_{3}=2.25$, were lower than those based on the Tveergard parameters assumed from the material properties, i.e. $\mathrm{q}_{1}=1.91, \mathrm{q}_{2}=0.79, \mathrm{q}_{3}=3.65$. The maximum difference between the force values was $3.7 \%$.

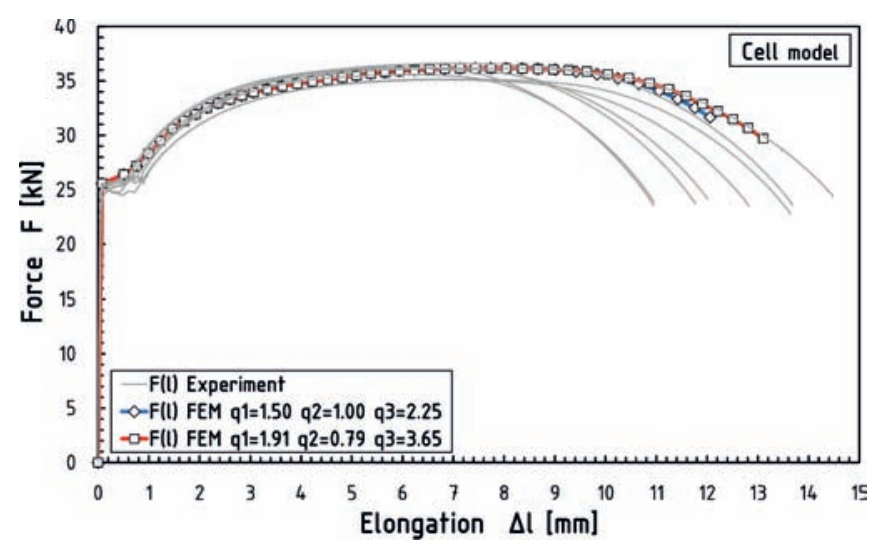

Fig. 10. Force vs. elongation curves determined experimentally and numerically using the Cell model

In the next part of the study, the void volume fraction, VVF, was analyzed. Generally, the void volume fraction is higher in the middle of an element than at the end of the area adjacent to the fracture plane. Thus, fracture is expected to initiate in the middle of an element. Figures 11 and 12 show the VVF curves for a point in the centre of the fracture plane, along the element axis.

When the GTN model was applied, the voids began to increase at $\Delta \mathrm{l}=7.0 \mathrm{~mm}$, which corresponded to the maximum force in the $\mathrm{F}(\Delta \mathrm{l})$ curves. However, rapid increase was observed for $\Delta \mathrm{l}=8.0 \mathrm{~mm}$ (Fig. 11).

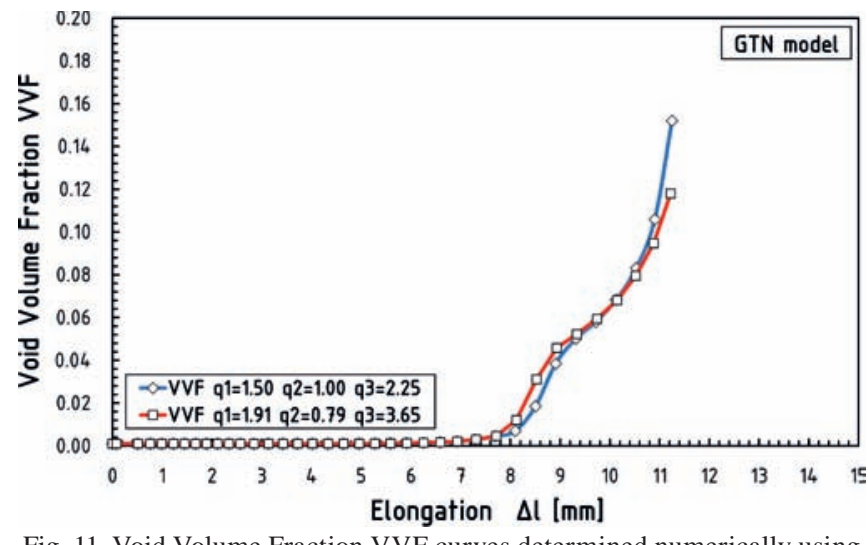

Fig. 11. Void Volume Fraction VVF curves determined numerically using the GTN model

Like in the strength curve analysis, the values of VVF differed. When $7.5 \mathrm{~mm}<\Delta \mathrm{l}<10.2 \mathrm{~mm}$, the values of VVF were higher for the Tvergaard parameters assumed from the material properties, i.e. $\mathrm{q}_{1}=1.91, \mathrm{q}_{2}=0.79, \mathrm{q}_{3}=3.65$, than for the typical ones, i.e. $\mathrm{q}_{1}=1.5, \mathrm{q}_{2}=1.0, \mathrm{q}_{3}=2.25$. The opposite tendency was observed for $\Delta \mathrm{l}>10.2 \mathrm{~mm}$ up to the failure. The maximum difference between the values of the void volume fraction was $28.9 \%$ at failure for both sets of the Tvergaard parameters.

In the Cell model, an increase in the void volume fraction was observed later than in the GTN model, i.e. at the elongation, $\Delta$ l, of about $8.0 \mathrm{~mm}$ (Fig. 12). 


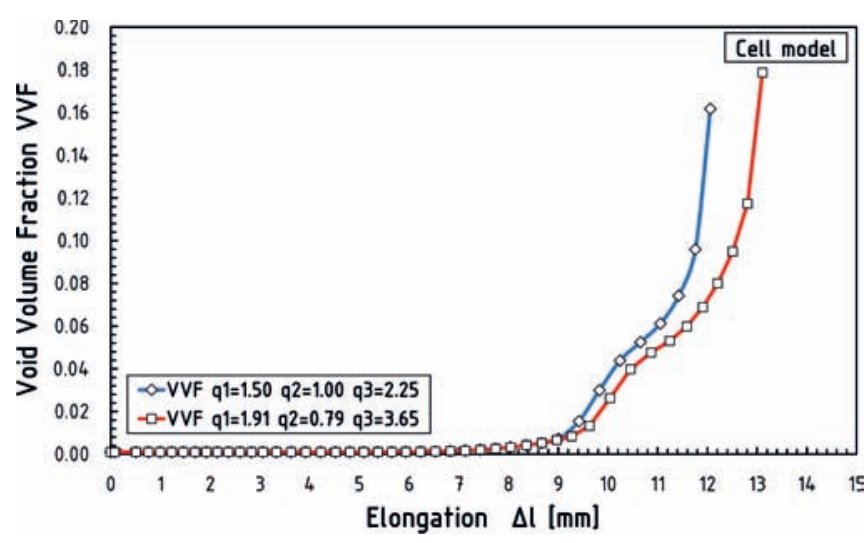

Fig. 12. Void Volume Fraction VVF curves determined numerically using the Cell model

Rapid increase in VVF was observed for $\Delta \mathrm{l}=9.0 \mathrm{~mm}$. When $\Delta \mathrm{l}>9.0 \mathrm{~mm}$, the values of VVF up to the failure were higher for the typical values of the Tvergaard parameters, i.e.: $\mathrm{q}_{1}=1.5, \mathrm{q}_{2}=1.0, \mathrm{q}_{3}=2.25$, than for the Tvergaard parameters based on the material properties: $\mathrm{q}_{1}=1.91, \mathrm{q}_{2}=0.79, \mathrm{q}_{3}=3.65$. The moment of failure is interesting because of the difference obtained for the two sets of the Tvergaard parameters. When typical values of qi are used, the failure is expected to occur at $\Delta \mathrm{l}=12.06 \mathrm{~mm}$, while for the material-based $\mathrm{q}_{\mathrm{i}}$, failure is observed at $\Delta \mathrm{l}=13.11 \mathrm{~mm}$.

\section{Discussion and conclusions}

The results obtained for the two sets of the Tvergaard parameters can be summarized as follows.

Firstly, for both numerical assumptions applied in this study, i.e. the GTN and the Cell models, there is a visible influence of the Tvergaard parameters on the load-carrying capacity of elements made of S235JR steel in the range from the maximum force up to the material failure. For the GTN model, the force values obtained by using the standard Tvergaard parameters, i.e. $\mathrm{q}_{1}=1.5, \mathrm{q}_{2}=1.0, \mathrm{q}_{3}=2.25$, were higher than those obtained by using the Tvergaard parameters based on the material properties, i.e. $\mathrm{q}_{1}=1.91, \mathrm{q}_{2}=0.79$, $\mathrm{q}_{3}=3.65$. This phenomenon is closely related with the void growth observed when the GTN numerical model is applied. In the range $7.5 \mathrm{~mm}<\Delta \mathrm{l}<10.2 \mathrm{~mm}$, higher values of VVF are noticed for the Tvergaard parameters assumed from the material properties than for the typical values leading to a reduction in the material strength, which indicates that the force values are lower when determined from the materialdependent values of $\mathrm{q}_{\mathrm{i}}$.

For the Cell model, differences between the values of force also occurred, but the opposite tendency was observed. The values of force obtained by using the standard Tvergaard parameters, i.e. $\mathrm{q}_{1}=1.5, \mathrm{q}_{2}=1.0, \mathrm{q}_{3}=2.25$ were lower than those obtained by using the Tvergaard parameters assumed from the material properties, i.e. $\mathrm{q}_{1}=1.91, \mathrm{q}_{2}=0.79, \mathrm{q}_{3}=3.65$. Like in the GTN numerical model, this was due to the void growth. When the typical values of $\mathrm{q}_{\mathrm{i}}$ were applied, the values of VVF were higher in the range $\Delta \mathrm{l}>9.0 \mathrm{~mm}$ up to the failure, which suggests a reduction in the load-carrying capacity of the element.

The moment of failure is interesting because for the two sets of the Tvergaard parameters, large differences were reported when the Cell model was applied. The expected failure was visibly earlier when the typical values of qi were used than when the material-based parameters $\mathrm{q}_{\mathrm{i}}$ were considered.

The following conclusions can be drawn from the present study:

1. The tensile strength curves obtained numerically by applying the GTN and the Cell models were consistent with the experimental results from zero to the maximum force $F$. Then, from that point to the material failure, the results differed. When the GTN model was used, softening was observed for a range above the maximum force. For the Cell model, the opposite was true.

2. In the GTN and the Cell numerical models developed for elements made of S235JR steel, the Tvergaard parameters had visible influence on the load-carrying capacity in the range from the maximum force to the material failure.

3. For the GTN model, the values of the force obtained by using the standard Tvergaard parameters, i.e. $\mathrm{q}_{1}=1.5$, $\mathrm{q}_{2}=1.0, \mathrm{q}_{3}=2.25$, were higher than those obtained using the Tvergaard parameters based on the material properties, i.e. $\mathrm{q}_{1}=1.91, \mathrm{q}_{2}=0.79, \mathrm{q}_{3}=3.65$. For the Cell model, the opposite phenomenon was reported.

4. For elements made of S235JR steel, the void growth defined by the void volume fraction (VVF), which corresponds to their load-carrying capacity, was also affected by the two sets of the Tvergaard parameters.

5. In the Cell model, failure was found to occur earlier when the typical values of $q_{i}$ were used.

\section{REFERENCES}

1. Abaqus 6.10. Analysis User's Manual, 2010, Dassault Systèmes Simulia Corporation, Providence.

2. Corigliano, A., Mariani, S. and Orsatti, B., 2000, "Identification of Gurson-Tvergaard material model parameters via Kalman filtering technique. I. Theory", International Journal of Fracture, Vol. 104, No. 4, pp. 349373.

3. Faleskog, J., Gao, X. and Shih, C.F., 1998, "Cell model for nonlinear fracture analysis - I. Micromechanics calibration", International Journal of Fracture, Vol. 89, No. 4, pp. 355-373.

4. Gurson, A. L., 1977, "Continuum theory of ductile rupture by void nucleation and growth: Part I - Yield criteria and flow rules for porous ductile media", Journal of Engineering Materials and Technology, Transactions of the ASME Vol. 99, No. 1, pp. 2-15.

5. Hancock, J.W. and Mackenzie, A. C., 1976, "On the mechanisms of ductile failure in high-strength steels 
subjected to multi-axial stress-states", Journal of Mechanics and Physics of Solids, Vol. 24, No. 2-3, pp. 147-160.

6. Kossakowski, P.G., 2010, "An analysis of the load-carrying capacity of elements subjected to complex stress states with a focus on the microstructural failure", Archives of Civil and Mechanical Engineering, Vol. 10, No. 2, pp. 15-39.

7. Kossakowski, P.G., 2012a, "Simulation of ductile fracture of S235JR steel using computational cells with microstructurally-based length scales", Journal of Theoretical and Applied Mechanics, Vol. 50, No. 2, pp. 589-607.

8. Kossakowski, P.G., 2012b, "Prediction of ductile fracture for S235JR steel using the Stress Modified Critical Strain and Gurson-Tvergaard-Needleman models", Journal of Materials in Civil Engineering, Vol. 24, No. 12, pp. 14921500 .

9. Kossakowski, P.G., Trąmpczyński, W., 2012, "Microvoids evolution in S235JR steel subjected to multi-axial stress state", Engineering Transactions, Vol. 60, No. 4, pp. 287314.

10.Kossakowski, P.G., 2012c, "Influence of initial porosity on strength properties of S235JR steel at low stress triaxiality", Archives of Civil Engineering, Vol. 58, No. 3, pp. 293-308.

11.Kossakowski, P.G., 2012d, "Effect of initial porosity on material response under multi-axial stress states for S235JR steel", Archives of Civil Engineering, Vol. 58, No. 4, pp. 445-462.

12.Kossakowski, P.G., 2012e, “The analysis of Tvergaard's parameters of S235JR steel in high triaxiality", Advances in Material Science, Vol. 12, No. 1, pp. 27-35.

13.Nahshon, K. and Hutchinson, J.W., 2008, "Modification of the Gurson Model for shear failure", European Journal of Mechanics - A/Solids, Vol. 27, No.1, pp. 1-17.

14.Needleman, A. and Tvergaard, V., 1984, "An analysis of the ductile rupture in notched bars", Journal of the Mechanics and Physics of Solids, Vol. 32, No. 6, pp. 461-490.

15.PN-EN 10002-1, 2004, Metallic materials - Tensile testing - Part 1: Method of test at ambient temperature, Polish Committee for Standardization, Warsaw.

16.PN-EN 1993-1-10, 2005, Eurocode 3 - Design of steel structures - Part 1: Material toughness and throughthickness properties, Polish Committee for Standardization, Warsaw.

17.Richelsen, A. B. and Tvergaard V., 1994, "Dilatant plasticity or upper bound estimates for porous ductile solids", Acta Metallurgica et Materialia, Vol. 42, No. 8, pp. 2561-2577.
18.Ruggieri, C., 2004, "Numerical investigation of constraint effects on ductile fracture in tensile specimens", Journal of the Brazilian Society of Mechanical Sciences and Engineering, Vol. 26, No. 2, pp. 190-199.

19.Sedlacek, G., Feldmann, M., Kühn, B., Tschickardt, D., Höhler, S., Müller, C., Hensen, W., Stranghöner, N. Dahl, W., Langenberg, P., Münstermann, S., Brozetti, J., Raoul, J., Pope, R. and Bijlaard, F., 2008, "Commentary and worked examples to EN 1993-1-10 "Material toughness and through thickness properties" and other toughness oriented rules in EN 1993”, JRC Scientific and Technical Reports, European Commission Joint Research Centre, Office for Official Publications of the European Communities, Luxembourg.

20.Tvergaard, V., 1981, "Influence of voids on shear band instabilities under plane strain conditions", International Journal of Fracture, Vol. 17, No. 4, pp. 389-407.

21.Tvergaard, V., 1989, "Material failure by void growth to coalescence", Advanced in Applied Mechanics, Vol. 27, pp. 83-151.

22.Tvergaard, V. and Needleman, A., 1984, "Analysis of the cup-cone fracture in a round tensile bar", Acta Metallurgica, Vol. 32, No. 1, pp. 157-169.

\section{CONTACT WITH THE AUTOR}

\author{
Paweł G. Kossakowski
}

\section{Department of Strength of Materials and Concrete Structures}

Faculty of Civil Engineering and Architecture

Kielce University of Technology

Al. Tysiąclecia Państwa Polskiego 7 25-314 Kielce, Poland

E-mail:kossak@tu.kielce.pl 